archaeology as a whole. Great opportunities will be presented in the discussions of the next few years. On the other hand there are risks involved, and chances that can be missed. In my opinion the most serious of these dangers has to be seen in the continuation of the 'cold war' between so-called 'positivist' and so-called

\section{References}

GoмвкіCH E.H. 1991. Die Krise der Kulturgeschichte: Gedanken zum Wertproblem in den Geisteswissenschaften. Munich: Deutscher Taschenbuchverlag.

KOSELLECK, R. 1989. Vergangene Zukunft: zur Semantik geschichtlicher Zeiten. Frankfurt-am-Main: Suhrkamp.

LAmberG Karlovsky, C.C. 1989. Introduction, in C.C. Lamberg-Karlovsky (ed.), Archaeological thought in America: 1-16. Cambridge: Cambridge University Press.

MeIER, C. \& J. Rüsen (ed.). 1988. Historische Methode: Theorie der Geschichte. Munich: Deutscher Taschenbuchverlag. Beiträge sur Historik 5.

MERAN, J. 1984. Theorien in der Geschichtswissenschaft: die 'post-positivist' positions. Clearly there exist many perceptions of the past - according to the ethnic, social, religious and political point of view of the author - but there is only room for one archaeology. Our hope is that it will be an archaeology exhibiting as many different facets and colours as possible.

\title{
Publishing urban archaeology
}

\section{AlaAN VinCE*}

J.R. PERRIN with D.F. WILLIAMS. The archaeology of York 16, fascicule 4: Roman pottery from the Colonia 2: General Accident and Rougier St. 140 pages, figures, tables, colour plates. 1990. London: Council for British Archaeology for the York Archaeological Trust; ISBN 0-906780-88-8 paperback $£ 15$.

C.M. BRooKs. The archaeology of York 16, fascicule 3: Medieval and later pottery from Aldwerk. London: Council for British Archaeology for the York Archaeological Trust; 128 pages, b/w plates ISBN 0-90680-66-7 paperback $£ 8.75$.

A.J. MaINMAN. The archaeology of York 16, fascicule 5: Anglo-Scandinavian pottery from Coppergate. 165 pages, illustrated. 1990. London: Council for British Archaeology for the York Archaeological Trust; ISBN 0-906780-89-6 paperback $£ 22.50$.

A.R. HALL \& H.K. KENWARD. The archaeology of York 14: The past environment of York fascicule 6: Environmental evidence from the Colonia: General Accident and Rougier Street. 145 pages, illustrated. 1990. London: Council for British Archaeology for the York Archaeological Trust; ISBN 0-906780-90-X paperback $£ 18$.

E.J.E. PIRIE. The archaeology of York 18, fascicule 1: Post-Roman coins.from York excavation 1971-81.83
Diskussion über die Wissenschaftlichkeit der Geschichte. Göttingen: Van den hoeck \& Ruprecht.

Souvský. B. 1970. Le problème des propriétés dans les ensembles archéologiques, in J.-C. Gardin (ed.), Archéologie et calculateurs, problèmes mathématiques et sémiologiques: Paris.

VeIt, U. 1990. Kulturanthropologische Perspektiven in der Urgeschichtsforschung, Saeculum 41 (3/4): 182-214. (= Urgeschichte als Kulturanthropologie. Beiträge zum 70 Geburtstag von K.J. Narr.)

WHITE, H. 1990. Die Bedeutung der Form. Erzählstrukturen in der Geschichtsschreibung. Frankfurt am Main: Fischer. pages, illustrated. 1986. London: Council for British Archaeology for the York Archaeological Trust; ISBN 0-900312-97-1 paperback $£ 9.50$.

T.P. O'CONNOR. The archaeology of York 15, fascicule 4: The animal bones: bones from 46-54 Fishergate. 89 pages, 10 figures, 8 plates, 22 tables. 1991. London: Council for British Archaeology; ISBN 1-872414-23-0 paperback $£ 12$.

These fascicules represent a good selection of the finds and environmental fascicules of the Archaeology of York series spanning a six-year period from 1986 to 1991. Comparing the earliest (18/1) with the latest $(15 / 4)$ we can see how the series has been gradually transformed in design and presentation whilst retaining a strong corporate image. The most striking change has been the use of a full colour cover but there are also changes of typography which serve to bring the appearance of the series up to date. Little touches, such as a discrete colour coded band on the spine, show the thought that has gone into the use of the fascicules and the standard of editing is extremely high.

The contents also follow a standard pattern. Each fascicule describes a class of finds or evidence from 
one or more YAT excavations. The archaeological context is briefly described and is followed by a description of the finds themselves. Discussion of the relevance of the finds to the sites interpretation and/or a general discussion follow as separate sections. In some cases this is followed or interleaved with a catalogue, either of all objects or of the illustrated examples. Then come French and German summaries, a bibliography, appendices (if any) and the plates. Here, too, there is evidence of a strong editorial line, imposing a framework on remarkably disparate types of data. By and large, when you open a YAT finds or environmental fascicule, you find what you are looking for where you expect to find it. As a publishing product the only criticism of these fascicules is that they are priced far too high for the readership for whom they were written, professional archaeologists and archaeological specialists.

The publication of archaological excavations is yet again under discussion following the circulation of 'Archaeological publication, archives and collections: Towards a national policy' (here abbreviated to Carver et al. (1992)) in January of this year. It is worth examining the YAT fascicules in the light of this paper although, of course, they have been prepared following criteria laid down in the early 1970s at the foundation of the Trust.

The policy proposed in Carver et al. (1992) is as follows:

1. A summary report should be written and depos. ited with the site archive.

2. This summary report should be published.

3. Further publication should not be an automatic goal of a post-excavation programme but the result of a conscious decision taken as a result of an assessment made during the post-excavation phase. To quote Carver et al. (1992):

'The principle here is that the form and scale of the publication should be commensurate with what the results have to offer rather than as a mechanistic process which is applied regardless of the quality and potential of the data concerned.'

4. A new annual publication should be produced in three parts:

Part 1 would list all archaeoogical work undertaken within the year.

Part 2 would contain summary reports of completed projects, stating the location of their archives.

Part 3 would consist of an annual review containing commissioned papers providing an over view of selected themes.

Let us now examine the premises which have lead to the latest call for a change in publication policy as they appy to York. It is stated in Carver et al. (1992) that the number of unpublished sites is growing rapidly. This should imply an increasing delay between excavation and publicaiton. In fact, in this admittedly small sample there is no discernible trend. In AY18/1 (1986) there was a gap of five years between the end of the most recent excavation and the publication of the fascicule whilst in AY15/4 (1991) there was still a gap of five years. The average delay was just under 7.5 years. Whilst that sounds horrific it has to be remembered that perhaps one year of that time would have been taken up in applying for plost-excavation funds and a further year in sending the fascicules through the editorial and publication process. If we add to that the difficulties of scheduling the work itself, since the authors were almost all staff of YAT or the EAU and therefore involved in other projects, then the delay is quite explicable. Furthermore, these fascicules were produced at a time when Information Technology and Desk-Top Publishing software were just coming into use in YAT, as elsewhere in archaeological units. It is too early to say what effect they will have on the growth or decline of a publication backlog.

There is, however, a curious phenomenon. None of the site reports which should accomplish these finds and environmental fascicules was published when the fascicules went to press. This I find a strange reversal of the order of things. On a complex urban excavation one starts the post-excavation process by checking the matrix against the site records and then, starting at the bottom of the sequence, one produces grouping of deposits, termed in York 'Context Series', which represent single events such as the construction of a building or the filling of a ditch. These events are then at York grouped together into Periods.

This basic outline of the site sequence is then passed across to finds and environmental specialists who can use it to assess the value of the material they have been presented with and then can devise a programme for analysis and publication. Meanwhile, illustrators can start to produce Period plans, sections, reconstructions and so on whilst the site report is being written. Admittedly, it is often necessary to modify the initial phasing as finds and environmental evidence is analysed but why YAT should consistently take longer to produce the final site report is bewildering. It may stem from the view that only the Site Director is capable of writing the site report. In the case of Coppergate (AY18/1, AY16/5, AY17/5) the site report has not yet appeared and the site summaries given in these fascicules give a selection of information (compare AY18/1 figure 2 and AY14/6 figure 215, both of which show Period 3 pits). In only one fascicule, AY14/6, is it clearly stated that the authors had access to a 'level III' report, demonstrating that the site's stratigraphic analysis had reached a conclusion. In other cases there must be a nagging doubt. Here, then, is a real cause for concern, but how might it be alleviated by the Carver et al. (1992) proposal to publish the site summary nationally?

The value of archaeological finds and environ- 
mental evidence comes from their archaeological context. Where finds are numerous the researcher must use the stratigraphic detail in the site report and in addition make decisions about the likelihood of intrusion and residuality and then present a summary of his or her conclusions. Where finds are scarce, as with individually recorded finds or samples, this step can be supplemented by including the context number on an accompanying plan and in the catalogue entry in the fascicule. In all of the fascicules reviewed here this cross-referencing can be done, or at least may be done once the site report has been published. The problem comes when describing more plentiful material, such as potsherds or animal bone fragments. It would plainly be a waste of paper to publish a full listing of the basic data. Very few people would want to go to the trouble of reworking the data and they can be served by the provision of data through the archive. Nevertheless it is only going to be possible for the reader to make valid comparisions from site to site, or from material to material on the same site, if there is a consistent policy for determining what level of detail to publish. Here, the numismatists lead the way, in that Pirie's fascicule uses the standard catalogue entry as devised for the Sylloge of Coins in the British Isles.

A function of fascicules such as these must be to make such analysis possible otherwise archaeological research will be limited to those with sufficient funds or hardware to access archaeological archives in person. The two post-Roman pottery fascicules for example have different formats. In one, AY $16 / 3$, a full listing of sherds per context is given while in the other, AY16/5, only the provenance of illustrated material is given to context level. Since the latter is the Coppergate fascicule, dealing with over 34,000 stratified sherds (excluding definite residual and intrusive material), one can see practical reasons why the fuller treatment was not given but one wonders whether the former is actually the ideal to which YAT should be working. My personal view is that both AY16/3 and AY16/4 publish far too much basic data, and in a form where it is not easy to synthesize whereas in the Coppergate fascicule it is not possible to reconstruct any assemblage smaller than a whole Period.

Lastly, one must tackle a final point brought up by Carver et al. (1992); the need to assess the value of material before committing it to print. Which, if any, of these YAT fascicules would have remained unwritten or in archive? Certainly not the Coppergate finds. The coin die and 'trial piece' are now wellknown through incorporation into several exhibition catalogues but one needs to see their archaeological context and to have a full description of them.
Similarly, the textiles are of international importance. They represent the largest assemblage of preConquest textiles from England as well as being closely dated through the site stratigraphy (unpublished though it still is). The Anglo-Scandinavian pottery is equally important and for the same reasons. There would be few dissenters from the proposition to publish the work of Hall and Kenward on the environmental evidence from the General Accident and Rougier Street sites in the Roman Colonia. Neither the sites nor the conclusions are unusual but the fascicule is a splendid case study showing what intensive environmental analysis can achieve. O'Connor's study of the Fishergate animal bones is likewise the product of a scientist in complete command of his material. Some of the speculation upon the interpretation of the results (p.276-87) goes well beyond what can be inferred from the evidence, but since it is quite clear in the text that these are hypotheses and speculations to be tested by further study and not conclusions this is quite justifiable, and completely in line with the Carver et al. (1992) proposal for Part 3 of the annual compendium where papers should 'generate debate and offer pointers to national research priorities'. We are left, then, with only two of the six which one might claim were the product of 'a mechanistic process applied regardless of the quality and potential of the data concerned'. What is needed for York to make further analysis and publication of pottery easier and more efficient is to produce a type series of fabrics and forms using selected dated or datable assemblages to provide information on frequency and chronology. For the Roman period, such a study has just begun.

To conclude, there are faults with these fascicules, or at least with the system which allowed them to appear before the stratigraphic report upon which they depend, but it is difficult to square the achievements of YAT, where adequate and long-term funding for archaeology has been present over a period of two decades, with the statement that 'the present situation is disorganised, highly labour intensive, costly and slow' (Carver et al. 1992). In my view what British archaeology requires is to protect the few adequately funded and well-managed units like YAT which still exist rather than promote another sweeping change of policy.

\section{References}

Carver, M., H. Chapman, B. Cunliffe, T. Hassall, M. HebDITCh, A. Lawson, I. LONGWORTh, R. MORris, D. PhILlipson, J. SCHOFELL \& G. WAINWRICHT. January 1992, privately circulated). Archaeological publication, archive and collections: towards a national policy. 